UDC 665.11

DOI: 10.15587/2706-5448.2021.237443

Article type «Reports on Research Projects»

\section{Denys Honcharov, Nataliia Tkachenko, Veronika Nikolaieva}

\title{
DEVELOPMENT OF FERMENTATION PARAMETERS OF MILK-FAT MIXTURES IN THE PRODUCTION OF SOUR CREAM PRODUCT WITH PHYTOSTEROLS
}

The object of research is a sour cream product with the addition of phytosterols in terms of the finished product from 0.141 to $1.710 \mathrm{~g} / 100 \mathrm{~g}$ of product. One of the most problematic places when using phytosterols is their extremely low solubility in water and fats. There are several ways to add phytosterols to foods. Direct application is represented by suspensions of phytosterol nanoparticles. To improve the solubility in water, phytosterols are converted into the form of glycosides. To improve the solubility in fats and oils, phytosterols are converted into fatty acid ethers. An important issue in the development of fermented milk products is the effect of phytosterols on the homogeneity of the system, the fermentation process, the final properties of the product. During the study, the introduction of pre-esterified phytosterols as a substitute for milk fat with a melting point of $32-34^{\circ} \mathrm{C}$ to milk-fat mixtures. Milk-fat mixtures of various compositions were fermented with the study of acidity during fermentation. To study the properties of the system, milk fat was replaced by vegetable fat by 25, 50, and $75 \%$. The content of lactic acid bacteria was determined for the final product and the organoleptic parameters of the product were compared. The results show that when fermenting for 14 hours, the required acidity parameters of pH 4.2 to 4.6, titratable acidity of 76 to $79^{\circ} \mathrm{T}$ were achieved at 12 hours. Phytosterols did not harm the fermentation rate, and after the process did not worsen the taste and appearance of the product. This provides the opportunity to obtain a high-quality sour cream product with additional properties. The process of fermentation of sour cream products with phytosterols corresponds to the parameters of the standard sour cream product and sour cream. This provides advantages such as the ability to integrate a new product into the sour cream and sour cream production system without significant changes in technology and equipment.

Keywords: sour cream product, milk fat substitute, suspensions of phytosterol nanoparticles, glycosides, fatty acid ethers.

\section{How to cite}

Honcharov, D., Tkachenko, N., Nikolaieva, V. (2021). Development of fermentation parameters of milk-fat mixtures in the production of sour cream product with phytosterols Technology Audit and Production Reserves, 4 (3 (60)), 37-41. doi: http://doi.org/10.15587/2706-5448.2021.237443

\section{Introduction}

The presence of significant amounts of cholesterol (cholesterol) is characteristic of all animal fats and a number of animal products. It should be taken into account that exogenous cholesterol, which enters the body with food during an unbalanced diet, can affect the balance of cholesterol in the blood and its transport system in the body. Long-term medical research shows that high serum cholesterol and an imbalance in the cholesterol transport system of low-density lipoprotein cholesterol (LDL) and high-density lipoprotein cholesterol (HDL), in turn, can cause atherosclerosis. As well as related cardiovascular diseases (CVD). Phytosterols (plant sterols and stanols) have a positive effect on the amount (LDL) and the overall lowering effect of cholesterol levels. Phytosterols are very close analogues of animal sterols and in particular cholesterol. The European Food Safety Administration recognizes the inclusion of stanols/sterols as a food ingredient as safe [1].

Cardiovascular diseases (CVD), mainly coronary heart disease and stroke, are the leading causes of death worldwide. These results were obtained from the 2019 GBD Global Burden of Disease Study. Medical studies for several decades have shown a link between the level of total cholesterol in the blood and the risk of heart disease. A meta-analysis of 22 primary and secondary prevention studies has convincingly shown that a decrease in total serum cholesterol reduces the incidence of coronary heart disease among survivors of myocardial infarction [2]. One of the main methods of reducing cholesterol levels is to increase the diet of plant - based phytosterol analoguesphytosterols [3]. A meta-analysis of 41 studies with various fortified foods found that the optimal daily dose of sterols or stanols is $2 \mathrm{~g} /$ day. This can lead to a $10 \%$ reduction in LDL levels, while higher doses provide only a small amount 
of additional effect [4]. Phytosterols and their compounds can be taken separately in the form of capsules, or as a component of food. Phytosterols are fractions of plant origin found in vegetable oils, seeds, nuts, cereals, and beans [5]. The main phytosterols in nature are beta-sitosterol, campesterol, and stigmasterol. They are saturated with phytosterols that do not have a double bond in the ring structure. Phytosterols and stanols are structurally similar to cholesterol (Fig. 1), therefore, they can be distinguished by the presence of additional methyl or ethyl groups in their side chain [6]. Therefore, phytosterols are able to replace cholesterol during the formation of micelles in the intestine due to their higher hydrophobicity, thereby reducing the absorption of cholesterol. In this regard, phytosterols play an important role in inhibiting the absorption of dietary cholesterol [7]. In this regard, the US Food and Drug Administration (FDA) and the European Union Nutrition Committee have approved phytosterols as safe food ingredients [8,9].

Dairy and milk-containing products occupy a large share in the human diet, are widely available on the market, have protein, carbohydrate and fat parts, include water-soluble and fat-soluble components. The combination of such features makes them the most advantageous food products for modification and enrichment in order to provide new taste, nutritional or health properties. Special attention should be paid to fermented milk products, which contain lactic acid bacteria and can be additionally enriched with probiotics. Due to the high potential of sour cream product was chosen to add phytosterols.

Sour cream product belongs to the category of dairy products. Sour cream-like products are widely used in sauces, salad dressings, potato sauces, as sauce enhancers, in cold soups and other foods. This type of dairy substitutes may have reduced fat content, it is more resistant to whey, its shelf life is longer, the cost is usually lower than natural dairy products.

In most cases, the recipes for sour cream substitutes include $15-21 \%$ fat, skimmed milk powder or sodium caseinate, stabilizers, sugar, emulsifiers. The production process includes mixing the components, pasteurization, and homogenization of the product before packaging. When pouring sour cream products have a liquid consistency. To prepare them, they must be refrigerated for 10 to 12 hours. At this time, the fat phase crystallizes, while proteins and stabilizers provide the desired consistency.

In the manufacture of sour cream substitutes and sauce bases, it is possible to use many options for combining fats. Initially, to ensure rapid melting of fat in the oral cavity as a substitute for milk fat (MAF) used coconut oil refined deodorized bleached (RDW) with a melting point of $24.4{ }^{\circ} \mathrm{C}$ or modified with a melting point of $33.3{ }^{\circ} \mathrm{C}$.
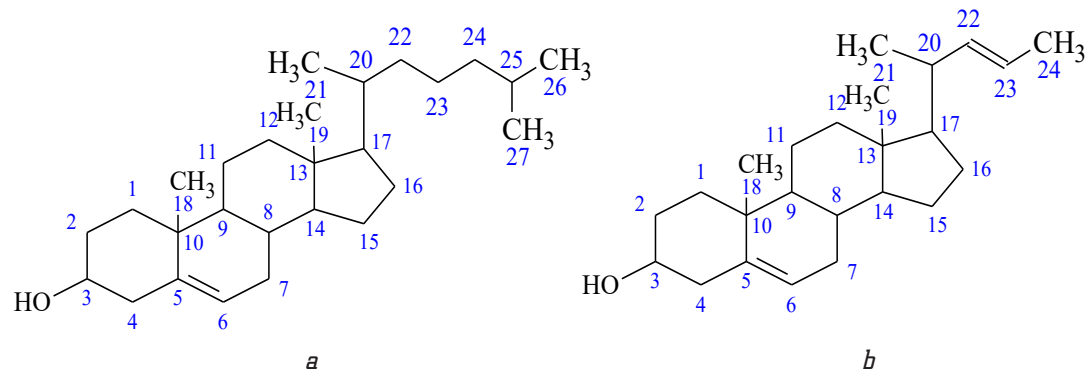

Fig. 1. Steral structure: $a$ - cholesteral; $b$ - brassicasteral
The melting properties of this tropical oil are due to the high content of lauric acid. Selectively hydrogenated cottonseed and soybean oil with a melting point of $35^{\circ} \mathrm{C}$. In combination with the steep slope of the melting curve provide stability of the finished product and specific taste sensations, while eliminating the possibility of the development of soap flavor caused by hydrolysis. Mixtures of hydrogenated under special conditions, or hydrogenated and fractionated vegetable oils can provide a more stable consistency compared to selectively hydrogenated sunflower oil and provide good organoleptic properties when consumed, despite the higher melting point [10]. However, in the production of milk fat substitutes using hydrogenated oil there is a problem with the presence of trans fats. An alternative to the method of hydrogenation in obtaining fats of specified properties is the method of transesterification.

First of all, the replacement of animal fats with vegetable was due to lower product costs, but current trends in healthy eating and vegetarian diet have led to demand for specialized foods with low cholesterol. However, recent studies suggest that a more influential factor in human health is not the total amount of cholesterol consumed but the maintenance of its balance in tissue metabolism [11].

Therefore, the possibility of introducing vegetable fats with phytosterols into dairy products, which have additional properties for regulating cholesterol metabolism, is relevant. Thus, the object of research is a sour cream product with the addition of phytosterols per finished product from 0.141 to $1.710 \mathrm{~g} / 100 \mathrm{~g}$ of product. And the aim of research consists in studying of features of fermentation of a sour cream product with partial replacement of milk fat on vegetable which contains esterified phytosterols.

\section{Methods of research}

During the study, laboratory samples of sour cream product were made, the fermentation stage was analyzed according to standard methods for determining acidity, the finished product was evaluated for the content of lactic acid bacteria and organoleptic parameters

The following components were used for preparation of sour cream product: milk of $2.6 \%$ of fat content of the GMZ trademark (TM) (Odessa, Ukraine), cow cream of $20 \%$ of fat of Prostokvashino TM (Kremenchuk, Ukraine), coconut oil (RDV), sweet cream butter peasant $82 \%$ fat. Fat component-substitute for milk fat with phytosterols. Yeast for sour cream of TM VIVO (Brovary, Ukraine) of structure Lactococcus lactis subsp. lactis, Lactococcus lactis subsp. diacetylactis, Lactococcus lactis subsp. cremoris, Streptococcus salivarius subsp. thermophiles. The number of lactic acid bacteria $1 \cdot 10^{10} \mathrm{CFU} / \mathrm{g}$.

Preparation of milk fat substitute. The product of transesterification of palm stearin, sunflower oil, palm kernel oil and phytosterols according to the previously published method was chosen as the basis of WMD [12]. To replace milk fat, 2 types of fat composition with a melting point of $34{ }^{\circ} \mathrm{C}$ were prepared. Type $13.8 \mathrm{~g}$ of phytosterol per $100 \mathrm{~g}$ of fat composition, type $2-11.4 \mathrm{~g}$ of phytosterol in fat composition. The preparation of sour cream product was carried out according to the ratios shown in Table 1. 
The ratio of components in the preparation of sour cream product

\begin{tabular}{|c|c|c|c|c|c|c|c|c|}
\hline Sample No. & 1 & 2 & 3 & 4 & 5 & 6 & 7 & 8 \\
\hline Milk fat substitute with phytosterols, 3.8 g/100 g & 15 & 10 & 5 & 0 & 0 & 0 & 0 & 0 \\
\hline Milk fat substitute with phytosterols, $11.4 \mathrm{~g} / 100 \mathrm{~g}$ & 0 & 0 & 0 & 0 & 15 & 10 & 5 & 0 \\
\hline Butter 82 \% fat, g/100 g & 0 & 0 & 0 & 6 & 0 & 0 & 0 & 0 \\
\hline Coconut oil, g/100 g & 0 & 0 & 0 & 0 & 0 & 0 & 0 & 15 \\
\hline Milk 2.6 \% fat, g/100 g & 68 & 45 & 23 & 21 & 68 & 45 & 23 & 68 \\
\hline Cream 20 \% fat, g/100 g & 16 & 44 & 71 & 71 & 16 & 44 & 71 & 16 \\
\hline The content of phytosterols in 100 g of product & 0.141 & 0.282 & 0.423 & 0 & 0.57 & 1.14 & 1.71 & 0 \\
\hline
\end{tabular}

Milk fat substitute with phytosterol was used to prepare a sour cream product of $20 \%$ fat. Milk fat (MF) was replaced by $25,50,75 \%$. For samples $1,5,8$, the ratio of $25 \%$ MF to $75 \%$ MF was chosen. For samples 2, 6, the ratio of $50 \% \mathrm{MF}$ to $50 \% \mathrm{WM}$ was chosen. For samples 3, 5, the ratio of $75 \% \mathrm{MF}$ to $25 \% \mathrm{MF}$ was chosen. Sample 4, for comparison - $100 \% \mathrm{MF}$. The sour cream product was prepared according to the following scheme: milk of $2.6 \%$ fat content was heated to $45^{\circ} \mathrm{C}$, and the emulsifier soy lecithin was stirred intensively. Milk fat substitutes were melted and heated to $45^{\circ} \mathrm{C}$, then mixed with milk base. Milk cream $26 \%$ fat was also heated to $45{ }^{\circ} \mathrm{C}$ and mixed into the total mixture. This was followed by pasteurization of the mixture at $90{ }^{\circ} \mathrm{C}$. The mixture was then cooled to $30{ }^{\circ} \mathrm{C}$. Yeast was added to the mixture and the fermentation process was carried out for 14 hours at $30{ }^{\circ} \mathrm{C}$.

The following methods of analysis were used: Active acidity was measured according to the method of GOST 26781-85 using a potentiometric pH analyzer HANNA HI98108 (Romania). The titrated acidity was determined according to the method of GOST 3624-92. Add $5 \mathrm{ml}$ of product to a $250 \mathrm{ml}$ flask and make up to $30 \mathrm{ml}$ with distilled water, mix thoroughly, add 3 drops of phenolphthalein solution and then titrate with $0.1 \mathrm{M}$ sodium hydroxide solution until a pale pink color is stable for 1 minute.

The number of lactic acid bacteria, as well as the absence of yeast and molds were determined on the basis of standard methods GOST 10444.11-2013 (ISO 15214:1998), GOST 10444.12-2013. Sowing of sour cream samples was performed on solid agar nutrient medium (MS). Emergency seeding was thermostated in a laboratory thermostat for 5 days at $37{ }^{\circ} \mathrm{C}$.
To determine the marketable properties of products, their organoleptic characteristics were determined according to the indicators listed in Table 2.

To reduce the probability of error, all samples were fed in the same container. Each sample had a code with a random six-digit number. All of them were presented to the test participants in a randomized manner.

\section{Research results and discussion}

During the preparation of the sour cream product with phytosterols, the acidity of the compositions was determined using a pH meter HANNA HI98108. Changes in active and titrated acidity (Fig. 2, 3) make it possible to monitor the rate of change in acidity when using sour cream for TM VIVO sour cream.

Based on the obtained data, it is possible to conclude that the first 2 hours there was an accumulation of energy to initiate the action of lactic acid bacteria. The most active fermentation was observed from 4 to 10 hours. From 12 to 14 hours the system did not show significant changes, probably due to an increase in the number of lactic acid bacteria and a decrease in raw materials for fermentation.

Since the titrated acidity of all 8 samples reached a value of from 60 to $100^{\circ} \mathrm{T}$, and the active acidity of the obtained sour cream product in the range from 4.8 to 4.2 , it is possible to conclude that the fermentation was successful. The product corresponds to the normative indicators of acidity for sour cream according to the normative documents of Ukraine, in particular, DSTU 4418:2005 «Sour cream».

Table 2

Score scale for determining organoleptic parameters

\begin{tabular}{|c|c|c|c|c|}
\hline $\begin{array}{c}\text { The value of } \\
\text { the score scale }\end{array}$ & Consistence & Taste & Odor & Color \\
\hline 1 point & $\begin{array}{c}\text { Strong graininess, the presence of } \\
\text { lumps/significant phase separation }\end{array}$ & $\begin{array}{c}\text { Strong unpleasant taste, not typi- } \\
\text { cal of fermented milk products }\end{array}$ & $\begin{array}{c}\text { Strong odor, not typical } \\
\text { of fermented milk products }\end{array}$ & $\begin{array}{c}\text { Dark, creamy, white spots on } \\
\text { a general background }\end{array}$ \\
\hline 2 points & $\begin{array}{c}\text { Large number of large bubbles, } \\
\text { significant grain size/slight phase } \\
\text { separation }\end{array}$ & $\begin{array}{c}\text { Highly perceptible foreign taste } \\
\text { on the background of the taste } \\
\text { of fermented milk product }\end{array}$ & Significant foreign odor & Cream uneven color \\
\hline 3 points & $\begin{array}{c}\text { The presence of a significant number } \\
\text { of bubbles, slight graininess/liquid } \\
\text { overall structure }\end{array}$ & $\begin{array}{c}\text { Sour milk taste with a sour } \\
\text { or weak bitter aftertaste }\end{array}$ & $\begin{array}{c}\text { No sour milk odor, weak } \\
\text { foreign odor }\end{array}$ & $\begin{array}{c}\text { White, with a cream tinge, } \\
\text { uneven in weight }\end{array}$ \\
\hline 5 points & $\begin{array}{c}\text { The presence of single bubbles, slight } \\
\text { graininess/density is satisfactory }\end{array}$ & $\begin{array}{c}\text { Sour milk taste with a weak } \\
\text { sour taste }\end{array}$ & $\begin{array}{c}\text { Weak sour-milk smell, } \\
\text { weak foreign smell }\end{array}$ & $\begin{array}{c}\text { White, with a cream tinge, } \\
\text { uniform throughout the mass }\end{array}$ \\
\hline 5 points & Dense, completely homogeneous & $\begin{array}{c}\text { Pure, fermented milk with a } \\
\text { taste characteristic of pasteurized } \\
\text { fermented milk product }\end{array}$ & $\begin{array}{c}\text { Pure, sour-milk with } \\
\text { a smell peculiar to the pas- } \\
\text { teurized sour-milk product }\end{array}$ & $\begin{array}{c}\text { White, uniform throughout } \\
\text { the mass }\end{array}$ \\
\hline
\end{tabular}




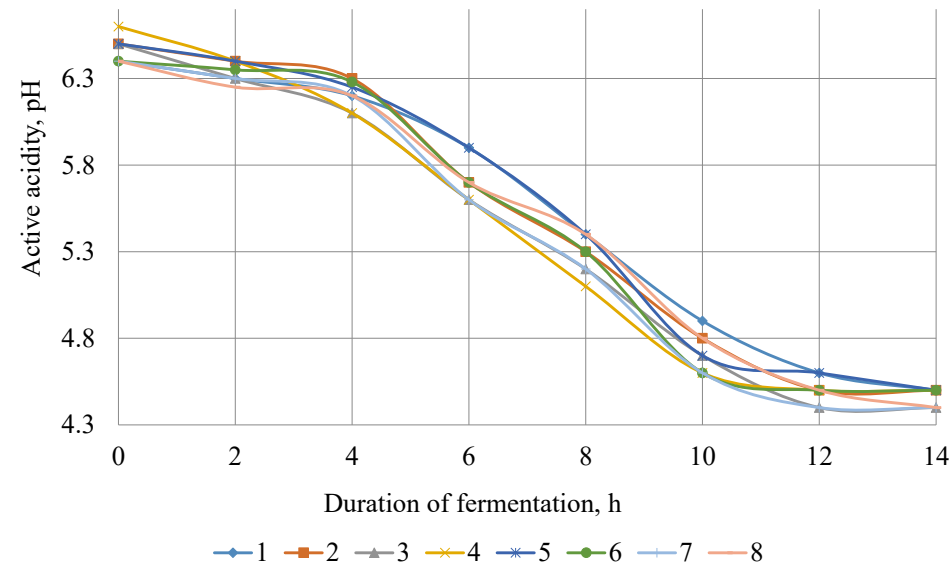

Fig. 2. Change in active acidity during fermentation

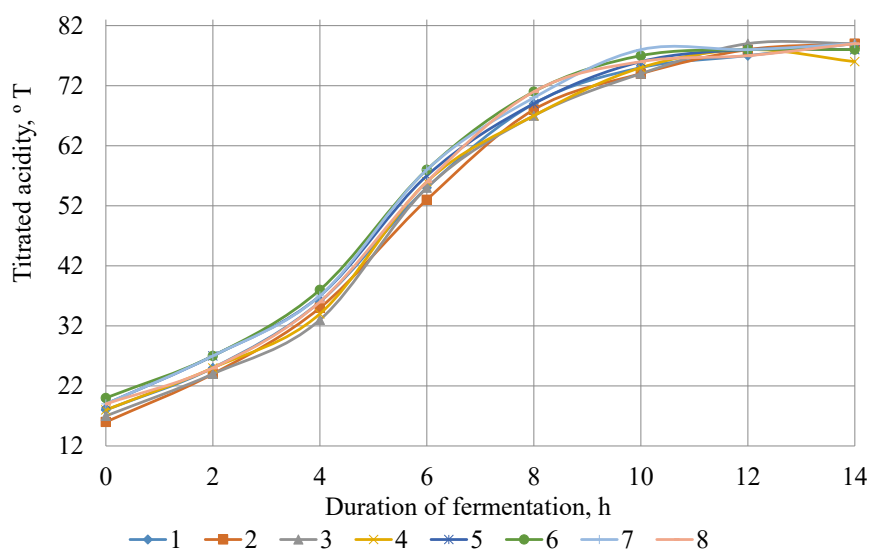

Fig. 3. Change of titrated acidity during fermentation

The obtained data show that the rate of change of acidity has no direct correlation with the amount of phytosterols in the fermentable composition. From this it is possible to conclude that the introduction of phytosterols into the composition does not significantly affect the fermentation rate. The introduction of phytosterols into the fat composition of the sour cream product does not impair the activity of the fermentation component and ensures the uniformity of the process.

After storage for 4 hours at a temperature of $4{ }^{\circ} \mathrm{C}$ determination of the activity of lactic acid bacteria (Fig. 4) showed that all samples have more than $1 \cdot 10^{7} \mathrm{CFU}$, which corresponds to the normative acidity for sour cream according to Ukrainian regulations, in particular, DSTU 4418:2005 «Sour cream».

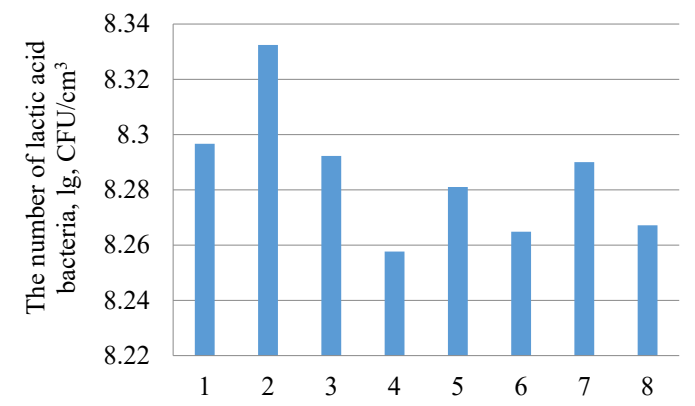

Fig. 4. The results of determining the activity of lactic acid bacteria

It should be noted that no traces of formation of colonies of yeast and molds were found. This indicates a low probability of contamination of samples and a low probability of external microbiological effects on fermentation processes.

Organoleptic parameters were determined after 4 hours of settling at $4{ }^{\circ} \mathrm{C}$ to allow the fermentation process to complete. Also, the exposure allowed to bring the samples to the same temperature and reduce the influence of external factors. Sensory characteristics of yogurt samples were evaluated by 5 unprepared participants in a uniformly lit room at approximately $25{ }^{\circ} \mathrm{C}$.

The products $1-8$ obtained during fermentation had a satisfactory appearance and taste (Fig. 5).

All samples had a stable consistency at the end of fermentation and transfer to the refrigerator at $4{ }^{\circ} \mathrm{C}$, no syneresis was observed. It should be noted that sample 4, for the preparation of which milk fat was used, had a more yellowish color. This can be caused by the specific content of carotenoids that are characteristic of milk fat. It is important to note that sample 8 after fermentation was noticeably rarer, compared to samples 1-7. From which it is possible to conclude that the fermentation of sour cream product with the addition of coconut oil does not provide the required consistency.

In the technological process, the use of coconut oil in a sour cream product may require the addition of rheological regulators.

It should be noted that the introduction of phytosterols by this technology is less effective for a low-fat sour cream product due to the fact that the increase in phytosterols in relation to the fatty phase of breast cancer can adversely affect the taste.
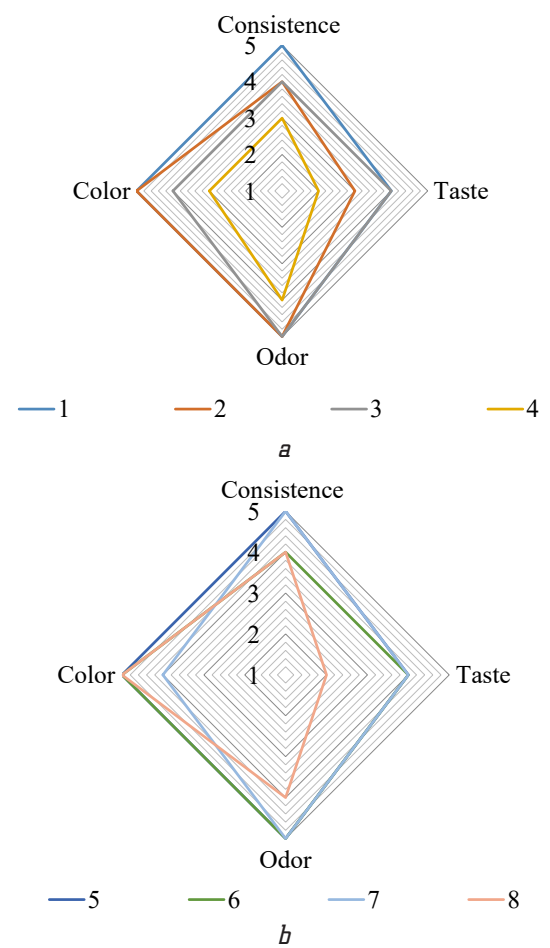

Fig. 5. Profilogram based on the results of determining organoleptic parameters: $a$ - samples $1,2,3,4$; $b$ - samples 5, 6, 7, 8 
Sour cream product with phytosterols produced by the described technologies is planned to be investigated for shelf life. In further research, the most promising area is the addition of new products, including probiotic properties.

\section{Conclusions}

The study found that the addition of phytosterols to the sour cream product by adding milk fat substitutes with esterified phytosterols provides stable fermentation of the product for 12 hours to $76-79^{\circ} \mathrm{T}, \mathrm{pH} 4.4-4.5$ and more than $1 \cdot 10^{7} \mathrm{CFU}$. The selected composition of the fat composition for the addition of phytosterols in the range of $0.141-1.710 \mathrm{~g} / 100 \mathrm{~g}$ of product allows to achieve satisfactory taste properties. The speed of the fermentation process, the endpoints and the resulting consistency also correspond to the sour cream product without the addition of phytosterols.

The research results will be useful for the production of sour cream product with phytosterols on the lines for the production of sour cream and sour cream product without significant changes in the design of equipment in the fermentation sector and with minimal adjustments in the process. It is advisable to further add antioxidants and vitamin sources to protect phytosterols from oxidative damage and increase the bioactive potential of the product. In the following studies, it is advisable to consider the shelf life of phytosterol-enriched sour cream product.

\section{References}

1. Chaudhari, P. R., Jain, A. K., Aparnathi, K. D. (2008). Phytosterol: A Functional Ingredient in Food. Indian Dairy Industry - Opportunities and Challenges, 165-169. Available at: https://www.dairyknowledge.in/sites/default/files/ch15_0.pdf

2. Pekkanen, J., Linn, S., Heiss, G., Suchindran, C. M., Leon, A., Rifkind, B. M., Tyroler, H. A. (1990). Ten-Year Mortality from Cardiovascular Disease in Relation to Cholesterol Level among Men with and without Preexisting Cardiovascular Disease. New England Journal of Medicine, 322 (24), 1700-1707. doi: http:// doi.org/10.1056/nejm199006143222403

3. Kritchevsky, D., Chen, S. C. (2005). Phytosterol-shealth benefits and potential concerns: a review. Nutrition Research, 25 (5), 413-428. doi: http://doi.org/10.1016/j.nutres.2005.02.003

4. Katan, M. B., Grundy, S. M., Jones, P., Law, M., Miettinen, T., Paoletti, R. (2003). Efficacy and Safety of Plant Stanols and Sterols in the Management of Blood Cholesterol Levels. Mayo Clinic Proceedings, 78 (8), 965-978. doi: http://doi.org/ 10.4065/78.8.965
5. Clifton, P. M., Noakes, M., Sullivan, D., Erichsen, N., Ross, D., Annison, G. et. al. (2004). Cholesterol-lowering effects of plant sterol esters differ in milk, yoghurt, bread and cereal. European Journal of Clinical Nutrition, 58 (3), 503-509. doi: http://doi.org/ 10.1038/sj.ejcn.1601837

6. AbuMweis, S. S., Vanstone, C. A., Ebine, N., Kassis, A., Ausman, L. M., Jones, P. J. H., Lichtenstein, A. H. (2006). Intake of a Single Morning Dose of Standard and Novel Plant Sterol Preparations for 4 Weeks Does Not Dramatically Affect Plasma Lipid Concentrations in Humans. The Journal of Nutrition, 136 (4), 1012-1016. doi: http://doi.org/10.1093/jn/136.4.1012

7. Ben Moussa, O., Mzoughi, M., Chouaibi, M., Boulares, M., Hassouna, M. (2019). The Combined Effect of Phytosterols and Lactulose Supplementation on Yoghurt Quality. Journal of Food and Nutrition Research, 7, 261-269.

8. Engel, R., Schubert, H. (2005). Formulation of phytosterols in emulsions for increased dose response in functional foods. Innovative Food Science EF Emerging Technologies, 6 (2), 233-237. doi: http://doi.org/10.1016/j.ifset.2005.01.004

9. Taşan, M., Bilgin, B., Geçgel, Ü., Demirci, A. Ş. (2006). Phytosterols as functional food ingredients. Tekirda ğ Ziraat Fakültesi Dergisi, 3 (2), 153-159.

10. O'Brayen, R. (2007). Zhiry i masla. Proizvodstvo, Sostav i Svoystva, Primenenie. Saint Petersburg: Professiya, 19-83.

11. Lemieux, I., Lamarche, B., Couillard, C., Pascot, A., Cantin, B., Bergeron, J. et. al. (2001). Total Cholesterol/HDL Cholesterol Ratio vs LDL Cholesterol/HDL Cholesterol Ratio as Indices of Ischemic Heart Disease Risk in Men. Archives of Internal Medicine, 161 (22), 2685-2692. doi: http://doi.org/10.1001/ archinte.161.22.2685

12. Honcharov, D. S., Tkachenko, N. A., Nikolaieva, V. G. (2021) Transeterification of a Mixture of Vegetable Fats with the Addition of Phytosterols. European Journal of Agriculture and Food Sciences, 3 (2), 45-48. doi: http://doi.org/10.24018/ ejfood.2021.3.2.252

$\triangle$ Denys Honcharov, Postgraduate Student, Department of Technology of Dairy, Oil and Fat Products and the Beauty Industry, Odessa National Academy of Food Technologies, Odessa, Ukraine, ORCID: https:// orcid.org/0000-0002-2472-5052, e-mail: dns93@ukr.net

Nataliia Tkachenko, Doctor of Technical Sciences, Professor, Department of Technology of Dairy, Oil and Fat Products and the Beauty Industry, Odessa National Academy of Food Technologies, Odessa, Ukraine, ORCID: https://orcid.org/0000-0002-2557-3927

Veronika Nikolaieva, Department of Organic and Pharmaceutical Technologies, Odessa Polytechnic State University, Odessa, Ukraine, ORCID: https://orcid.org/0000-0002-7904-9725

$\triangle$ Corresponding author 